\title{
Feasibility study on adjustment of injection-production system in extremely high water cut period
}

\author{
Guoqiang $\mathrm{Cao}^{1}$ \\ ${ }^{1}$ The 3rd Oil Production Factory, Daqing Oil Field Company Ltd, Daqing, China
}

\begin{abstract}
Entering the stage of ultra-high water cut development, affected by faults and irregular well patterns in some areas, there are problems in the development of oilfields such as imperfect injection-production systems, high oil-water wells ratio, low multi-directional connectivity ratio, and complex injection-production relationships. To this end, combined with well seismic and fine reservoir research results, the feasibility study of the injection-production system adjustment was carried out, based on the fine adjustment of the strata well pattern, and through new drilling, supplementary drilling, re-injection, re-production, etc. The well pattern connection rules are conducive to the purpose of adjustment, thereby increasing the recovery rate and improving the effect of oilfield development.
\end{abstract}

\section{Analysis of the main contradictions in development and the necessity of adjustment of injection-production system}

Area A was put into development in 1964, and polymer flooding started in 1994. It has entered the stage of ultra-high water cut exploitation. The two floods of water and polymer coexist, and multiple sets of well patterns are jointly exploited. When the injection-production system was adjusted in 2004, the adjustment was mainly aimed at the water flooding intensification adjustment layer system. The reverse nine-point area well pattern was converted to the five-point method and the horizontal linear well pattern. The oil-water well ratio decreased from 2.15 to 1.44 , but Affected by factors such as the development of local faults and the complementary utilization of strata, the ratio of oil-water wells in the whole area is still high; and some water drive wells are used by polymer flooding well patterns to block water flooding production horizons, resulting in local injection and production failures. Perfect, the proportion of multi-directional connectivity is low, only about $40 \%$, which affects the development effect.

\subsection{Unreasonable injection and production system in the evolution of well pattern}

One is that water drive wells are used by polymer flooding, and the corresponding water drive layer is blocked, resulting in imperfect injection and production of water drive well patterns in some areas. The second is the complementary utilization of strata in some areas, combined injection and combined production of good and bad oil layers, and long production intervals and prominent contradictions between layers. The third is the coexistence of the linear well pattern and the five-point method area well pattern. The injection-production relationship in the connection area is not perfect and the degree of control is low. (Figure 1) 
Lack of well points after polymer flooding

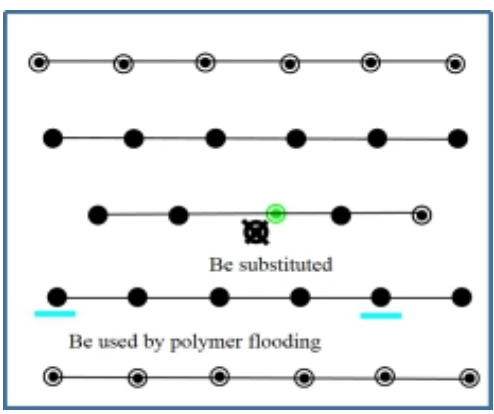

The linearity and the five-point method are not well connected

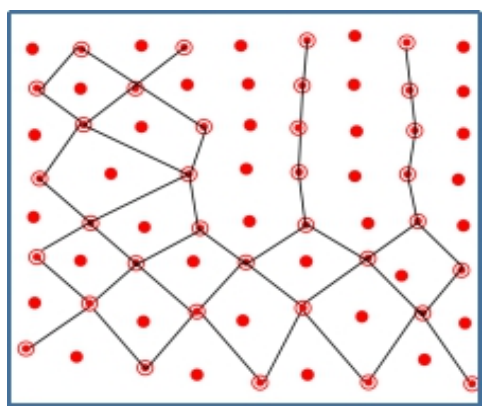

Big contradiction between layers due to the complementary use of layers

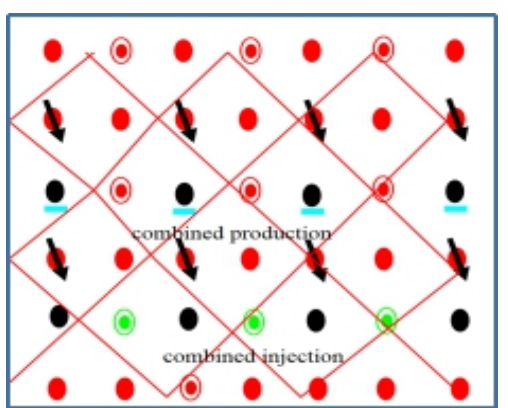

Figure1. Schematic Schematic diagram of well network connection

\subsection{The injection production is not perfect in the fault zone, and the control of well pattern is low}

The intensive fault region has 18 faults. The sand bodies in the area are cut into narrow strips by faults, and the spread area is small. The phenomenon of one injection and one mining or whether there is mining or not is serious. The degree of water flooding control is only $82.7 \%$, and the proportion of unidirectional and bidirectional connectivity is higher, reaching $62.9 \%$, and the proportion of multi-directional connectivity is only $19.8 \%$. The water content of oil production wells in the fault-intensive area is lower, $1.6 \%$ lower than that in the non-fault area. The injection-production system needs to be further improved.

\subsection{The pressure level is low and the production condition is poo}

Affected by factors such as high oil-water wells ratio and imperfect injection-production relationship in local areas, the formation pressure level in this area is low. From the perspective of plane pressure distribution, the pressure at each well point is quite different and the pressure distribution is not balanced. From the production status of various oil layers, the data of Airtight coring wells, and the interpretation data of water-flooded layers, there are also big differences in the production of oil layers.

\section{Research on well-seismic fine reservoir technology}

The area completed the acquisition of high-density 3D seismic data in 2008. On this basis, the traditional geological modeling process is used to import seismic data to control, based on the faults of seismic interpretation, using advanced fault detection such as coherence cubes, Intersecting lines, horizontal slicing, dip angle analysis and other technologies can realize the spatial homing of breakpoints, the spatial combination of faults, and the realization of fault occurrence. The first is the study of the fine time-depth relationship and the three-dimensional space-time variable velocity field to realize the coordinated analysis of well and seismic data. The "ant body"-based edge detection technology extracts seismic attributes, adjusts the occurrence of large faults and changes in end extension according to the breakpoints, assists in the identification of unexplained low-order faults and the establishment of the spatial combination of faults; then Comprehensive point (well breakpoint guide), line (orthogonal seismic slice), surface (fault trend surface), body (ant body and other seismic attribute bodies) multi-data, multi-window combination of breakpoint spatial homing combination and fault Modeling and confirming the spatial distribution characteristics of faults and fractures. Compared with the original knowledge, the strike and dip of the fault have not changed much, and the combination relationship and extension length have changed greatly. 26 faults were originally recognized, 47 faults were interpreted by well-seismic combination, of which 13 were newly combined faults, 4 were write-off faults, and 8 faults were fragmented into 20 . In the later period, combined with pulse well testing and dynamic data analysis methods, the fault results were verified and implemented, which provided a reliable basis for adjusting and tapping the potential of fault areas.

\section{Adjustment and effect analysis of well-seismic combined injection-production system}

Aiming at the existing problems in the area, according to the combination of well and seismic research, fine adjustment based on layer pattern, take up the drill, transfer, transfer of mining, plugging etc., perfect layered injection production relationship, slow down the difference between layers, to improve the development effect

Re-drilling the wells used by polymer flooding and the complementary replacement wells of strata systems to improve the water flooding injection-production relationship. Based on the injection-production 
relationship of the original well pattern, make up for well locations that are used by polymer flooding and replaced by other formations, and at the same time plug the original combined production wells for the new drilling and production target layer, and improve the injection-production relationship. At the same time, shorten the mining well section and reduce the difference between layers.

Based on the principle of well pattern rules and good connection relationship, for areas with imperfect injection-production and poor well pattern connection, a regular five-point method area well pattern is formed by means of new drilling or re-injection to improve the injection-production relationship.

In the fault-intensive area, re-recognize the results of the fault distribution based on the combination of wells and earthquakes, combined with the development characteristics of the oil layer and the current production situation, and use the method of continuing the original well pattern injection-production relationship to improve the injection-production relationship of each set of series by drilling new wells and transferring some well points.

After the adjustment, a total of 184 new wells (81 injection wells and 103 production wells) were drilled in the whole area, 35 were re-injected, and 9 were reproduced. At the same time, 65 wells were plugged and 44 wells were repaired. The ratio of the number of oil-water wells in the water flooding well pattern decreased from 1.44 before the adjustment to 1.18 , and the degree of water flooding control increased from $91.6 \%$ to $93.5 \%$. The proportion of multi-directional connectivity increased from $39.3 \%$ to $50.8 \%$, an increase of $11.5 \%$. It is expected to increase the recovery rate by 2.2 percentage points and increase the recoverable reserves by 1.245 million tons.

\section{Conclusion and understanding}

4.1 In view of the problems of high oil-water wells ratio, imperfect injection and production in some well areas, and unclear stratification in water flooding during the ultra-high water cut period, it is necessary to carry out adjustments to the injection and production system.

4.2 Clear strata, independent well pattern, perfect injection and production, and connection rules are conducive to comprehensive adjustments in the later stage and improvement of the development effect of the block.

4.3 The adjustment of the injection-production system should comprehensively consider the connection between the existing well pattern and subsequent development adjustments, conduct overall research, coordinate deployment, optimize the design, and adjust gradually.

Table1 Adjustment results of the injection-production system in the west of the pure oil area

\begin{tabular}{|c|c|c|c|c|c|c|c|c|c|c|c|}
\hline \multirow[t]{3}{*}{ Block } & \multirow{3}{*}{\multicolumn{2}{|c|}{$\begin{array}{l}\text { Stratum well } \\
\text { pattern }\end{array}$}} & \multirow{3}{*}{$\begin{array}{c}\text { Ratio } \\
\text { of oil } \\
\text { and } \\
\text { water } \\
\text { wells } \\
\text { before } \\
\text { adjust } \\
\text { ment }\end{array}$} & \multicolumn{4}{|c|}{$\begin{array}{c}\text { Injection Production System } \\
\text { Adjustment Area }\end{array}$} & \multicolumn{3}{|c|}{ Well-seismic fault zone } & \multirow{3}{*}{$\begin{array}{c}\text { Ratio of } \\
\text { oil and } \\
\text { water } \\
\text { wells } \\
\text { after } \\
\text { adjust } \\
\text { ment }\end{array}$} \\
\hline & & & & \multicolumn{2}{|c|}{ New drill } & \multirow{2}{*}{$\begin{array}{c}\text { wells } \\
\text { were } \\
\text { re-inje } \\
\text { cted }\end{array}$} & \multirow{2}{*}{$\begin{array}{c}\text { wells } \\
\text { were } \\
\text { reprod } \\
\text { uced }\end{array}$} & \multicolumn{2}{|c|}{ New drill } & \multirow{2}{*}{$\begin{array}{c}\text { wells } \\
\text { were } \\
\text { re-inje } \\
\text { cted }\end{array}$} & \\
\hline & & & & Oil ell & $\begin{array}{l}\text { water } \\
\text { well }\end{array}$ & & & $\begin{array}{c}\text { Oil } \\
\text { well }\end{array}$ & Subtotal & & \\
\hline \multirow[t]{5}{*}{$\begin{array}{l}\text { researc } \\
h \text { area }\end{array}$} & \multirow{2}{*}{$\begin{array}{c}\text { Well } \\
\text { patter } \\
\text { n } 3\end{array}$} & $\begin{array}{c}\text { Block } \\
1\end{array}$ & 1.54 & 2 & 5 & & & 6 & 1 & & 1.52 \\
\hline & & $\begin{array}{c}\text { Block } \\
2\end{array}$ & 1.54 & 37 & 38 & 12 & 8 & 17 & 2 & 4 & 1.43 \\
\hline & \multicolumn{2}{|c|}{$\begin{array}{l}\text { Water flooding } \\
\text { subtotal }\end{array}$} & 1.41 & 8 & 9 & 8 & 1 & & 3 & 2 & 1.28 \\
\hline & \multicolumn{2}{|c|}{ Type II oil layer } & 1.16 & 12 & 4 & 6 & & 4 & 2 & & 1.11 \\
\hline & \multicolumn{2}{|c|}{ total } & 1.44 & 59 & 56 & 26 & 9 & 27 & 8 & 6 & 1.35 \\
\hline
\end{tabular}

\section{References}

1. Fang, Yj. Liu, DQ; Wang, TZ.Zheng, ML.Lou, HC. Research on adaptability evaluation and adjustment method of injection-production system in La Saxing
Oilfield. Daqing Petroleum Geology and Development. 03, 72-75 (2007).

2. Zhou, XM.Sui,XG.Liu,DQ.Wang,ZQ.Research and discussion on the adjustment of injection-production systems in $\mathrm{La}$, Sa, and Xing oilfields. Daqing 
Petroleum Geology and Development. 03, 31-38.(1991)

3. Chen, F. The fine potential tapping model of the western fault zone in Sabei Development Zone. Journal of Yangtze University (Self Science Edition). 17, 39-43+5. (2016)

4. Wan, XD. FanG,Q.Lin,L.Zeng,XM.Practice and understanding of the adjustment of the injection-production system in the north and east of Saertu Oilfield. Daqing Petroleum Geology and Development. 01, 67-69, (2006) 